\title{
Islamic architecture in Tbilisi and Batumi: Muslim heritage in Georgia
}

\author{
Aldona Piwko
}

\author{
Aldona Piwko \\ Prof. Aldona Piwko, PhD \\ Vistula University in Warsaw \\ e-mail: a.piwko@vistula.edu.pl \\ ORCID: 0000-0003-2300-4306
}

Muzeológia a kultúrne dedičstvo, 2021, 9:4:69-83

DOI: $10.46284 / \mathrm{mkd} .2021 .9 .4 .5$

\section{Islamic architecture in Tbilisi and Batumi: Muslim heritage in Georgia}

Georgia's cultural wealth is the result of the country's centuries-old history and complex ethnic, religious and political relations. Islam, present in these areas since the seventh century, was of significant importance for the shaping of Georgian architecture. Architectural elements characteristic of Middle Eastern art were thus transferred to a Christian country. Arabs and Persians left behind buildings and ornamental details. The article is the result of field research carried out in Georgia, the purpose of which was to identify the issues of shaping and preserving memory and cultural and religious identity in the Muslim community. Georgian Muslim architecture is heavily neglected and requires increased protection, and above all significant financial resources that are difficult to obtain from a small number of Islamic communities. On the other hand, contemporary trends in Georgian architecture are realized and financed by Muslim businesses.

Keywords: Christianity, Islam, cultural heritage, architecture, Georgia

\section{Introduction}

Georgia is the second country in the world, after Armenia, to have adopted Christianity, recognizing it as a state religion. This happened in 337, thanks to the activity of the female apostle, Nino, who is canonized as a saint in the Catholic, Armenian and Orthodox churches, and is also the main patron saint of Georgia. ${ }^{1}$

Throughout its history, Georgia has been a state of many nations, different religions and several languages. Christianity is represented by the largest number of believers, with $87 \%$ of the inhabitants identifying as Christian. In Georgia, a commonplace statement is that "to be Georgian means to profess Orthodoxy". ${ }^{2}$ At the same time, being an Orthodox Christian does not only have a religious dimension, it is also, and often above all, an expression of national identity. The second religion in terms of number of followers is Islam, adhered to by nearly $11 \%$ of the population, while other religious traditions' followers number less than $0.1 \%$ of the population. ${ }^{3}$

\footnotetext{
${ }^{1}$ CHERKASOV, Aleksandr, KOROLEVA, Larisa, BRATANOVSKII, Sergei. SMIGEL, Michal. Sacred pagan temples in the Caucasus region: characteristic features. In: Muzeológia a kulturne dedičstvo, 6, 2018, pp. 59-60.

${ }^{2}$ CORSO, Molly. Georgia: What's the Definition of Tolerance? https://eurasianet.org/s/georgia-whats-the-definition-of-tolerance (accessed 22 January 2021).

${ }^{3}$ COUNTRY WATCH. Georgia. 2018 Country Review. Houston: CWInc., 2018, p. 277; SUNY, Ronald. The mother of cities: Tbilisi/Tiflis in the twilight of empire. In: VAN ASSCHE, Kristof. SALUKVADZE, Joseph (Ed.). Urban culture and urban planning in Tbilisi: Where west and east meet. Lewiston: Mellen Press, 2009, pp. 17-58.
} 
Islam has a long history in Georgia. The first Muslims arrived in Tbilisi as early as the first half of the seventh century, with the Arab conquest. Georgia was conquered by the Arab Army in 654, but only in 735 did they gain a clear control over a large part of the country, thereby establishing Muslim rule in Tbilisi. During their initial reign, the Arabs oppressed the Georgian community. Adult men were killed, women were abducted and sold at slave fairs, while young boys were castrated and prepared to serve as eunuchs in Arab harems. ${ }^{4}$

At the same time, subsequent emirs who ruled over the region cared for the economic and cultural development of the country. For this reason, Georgia gained in importance as a major scientific and literary centre. The exchange of ideas and views fuelled scientific debate and led to the emergence of numerous and, above all, valuable treaties. Tbilisi was perceived as one of the most intensively developing and richest cities of the Middle East. Its development also took place on the infrastructural level. Monumental public buildings were erected, inspired by the traditions of Islam. It was in this period that mosques, caravanserai, bazaars, bathhouses, palaces for the Arab aristocracy and houses for wealthy burghers were built. ${ }^{5}$

Until the end of the eleventh century, in Tbilisi there was an emirate, from which the Arabs ruled the Caucasus. However, Georgian aspirations for liberation from Arab rule and a return to independence rule were very strong and motivated the local rulers to engage in battle. King David IV defeated the Seljuk Turks, and in 1122 the Georgian army regained control over Tbilisi, which was Muslim at that time. This put an end to the 400 -year rule of Islam. ${ }^{6}$ Muslims again enslaved Georgia at the beginning of the sixteenth century, with the reign of the Ottoman Empire. The Persian invasion led by Aga Muhammad Khan toward the end of the 18th century, along with the lack of help from Tsarist Russia, caused the devastation of Georgia, and ultimately led to its absorption by Russia. ${ }^{7}$ Georgia gained full independence with the collapse of the Soviet Union in 1991, but to this day the state faces aggression from the Russian Federation, which controls Abkhazia and South Ossetia.

The centuries-old presence of Muslims in Georgia has left numerous traces that can be found in architecture. Well-preserved monuments of Islamic tradition can be admired primarily in the capital of the country, Tbilisi. However, also of note is the mosque in Batumi, the capital of Adjara, where the majority of Muslims in Georgia live. Currently, Islam is treated as a traditional religion of a minority of Georgian society, but it is also followed by people from the Caucasus, ${ }^{8}$ mainly Azeris and Chechens, who live in Georgia. ${ }^{9}$

The literature on Islam and Muslims, as well as Muslim art and architecture in Georgia, is not extensive, probably because for many decades Georgia was part of the Soviet Union. ${ }^{10}$ Research on Georgian Islam did not develop intensively until the t century. One person whose

\footnotetext{
4 BARANOWSKI, Bogdan, BARANOWSKI, Krzysztof. Historia Gruzji [History of Georgia], Warszawa: Ossolineum, 1987, pp. 36-37.

${ }^{5}$ Ibidem, pp. 37-38.

${ }^{6}$ ASATRIAN, Garnik, MARGARIAN, Hayrapet. The Muslim community of Tiflis (8th-19th Centuries). In: Iran and the Caucasus, 8(1), 2004, pp. 29-30.

${ }^{7}$ MATERSKI, Wojciech. Gruzja [Georgia]. Warszawa: Trio, 2000, pp. 19-24.

${ }^{8}$ SMIGEL, Michal, CHERKASOV, Aleksandr, KMET', Miroslav. Life and traditions of Caucasian Circassians: historical-comparative probe of travelogues of European travellers from the beginning of the 16th century to the half of the 19th century. In: Mureológia a kulturne dedičstvo, 5, 2017, pp. 32-34.

${ }^{9}$ PRASAD, Connor. Georgia's Muslim Community: A Self-Fulfilling Prophecy? Flensburg: European Centre for Minority Issues, 2012, p. 4.

${ }^{10}$ ANANIEV, Vitaly. Fyodor Shmit's "Social Museum”: On the Theorization of the Form and Purposes of Museums in Early Soviet Russia. In: Muzeológia a kultúrne dedićstvo, 6, 2018, pp. 33-35.
} 
work has made a significant contribution to the development of research on Georgian Islam is Giorgi Sanikidze, a Professor and Director at Giorgi Tsereteli Institute of Oriental Studies at the Ilia State University, Tbilisi.

The presentation of Muslim architecture in Georgia in this article is the result of interdisciplinary scientific research conducted in Batumi and Tbilisi, in collaboration with Sulkhan-Saba Orbeliani Teaching University, Tbilisi. The study is based on qualitative research conducted by means case studies of selected buildings associated with Georgia's Islamic heritage. The research was carried out by means of personal observations of the buildings, taking and analysing photographs, and archival research. An important element of the research was personal conversations with the curator of the mosque in Tbilisi and Georgian students during a scientific seminar.

\section{Muslim architecture and art in Georgia}

The Communist era significantly contributed to the degradation of many monuments in Georgia. The architectural traces of Arabs, Turks and other followers of Islam shared the same fate. Many examples disappeared forever as a result of various battles, the passage of time, or simply destructive human activity aimed at eliminating traces of another religious tradition. Two female architects - Suzanne Harris-Brandts, a Canadian architect and PhD student in urban studies and planning at the Massachusetts Institute of Technology, and Angela Wheeler, a PhD student in architecture at Harvard University's Graduate School of Design - with support from the Graham Foundation and Open Society Georgia, conducted research on wooden mosques in Adjara, which are in danger of ruin, and undoubtedly are of great historical value for the followers of Islam in the region.

Some architectural monuments have been restored, and Muslim art survives in Georgia

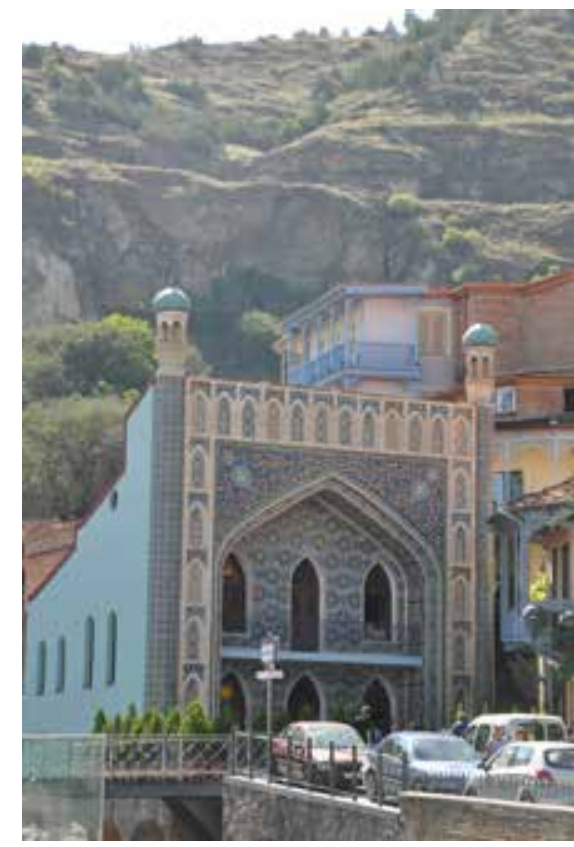

Fig. 1: Persian style sulfuric baths to this day. Of particular note is the historic mosque in Batumi, crowned with a golden dome, with a slim pencil minaret towering over the city, referring in its architecture to the mosque towers inscribed on the Istanbul landscape. However, in the capital of the country, Tbilisi, in addition to the mosque, there are other monuments that follow traditional Arab-Muslim construction styles. In addition, mosques in various parts of the country also deserve attention, as their architecture draws upon local construction techniques.

\section{Islamic architecture in Tbilisi}

Abanotubani is an ancient district of Tbilisi, famous for its sulphur springs. Legend has it that this historical part of the city was founded by King Wachtang Gorgasali. During a hunt, a royal falcon grabbed a pheasant and disappeared from the sight of the hunters. After a long search, the birds were found near a spring, scalded with hot water. Thus, the hot springs were discovered, and the king ordered a town 
to be established there. He called it Tbilisi, which, in Georgian, means warm. ${ }^{11}$ Persian-style sulfuric baths were built (Fig. 1), as well as the only mosque that survives to this day. Particularly noteworthy in this district is the cobbled Botanikuri Street, which leads to the mosque and on to the National Botanical Garden in Tbilisi.

\section{Jumah Mosque}

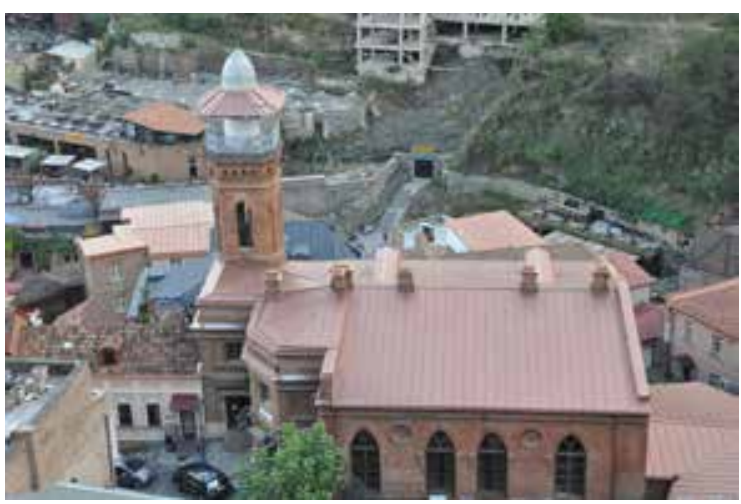

Fig. 2: Jumah Mosque in Tbilisi
Tbilisi is home to a mixture of various denominational and monotheistic religions. Jumah Mosque (Fig. 2) is a tangible example of this diversity and religious openness. It was located in the ancient district of Abanotubani, on the route leading from the churches and the synagogue. The exact address of the mosque is 32 Botanikuri Str. The first mosque in Tbilisi, it was built on the site of a destroyed Christian church in the sixteenth century. It belonged to the Shi'a religious community, and its founder was Sultan Suleiman the Magnificent, in 1522. ${ }^{12}$ The historic building, known as the Blue Mosque or the Shah Abbas ${ }^{13}$ Mosque, has not survived, having been demolished in 1951 to make way for the construction of the Metekhi Bridge. However, there are theories suggesting different motives for the destruction of the Shi'a mosque, such as the communist Georgian Soviet Socialist Republic authorities' disapproval of Shi'a religious practice, particularly in relation to the celebration of Ashura Day. This is the most important holiday in the Shi'a community since, it marks the death of the martyr Husayn, grandson of Muhammad, in the year 680, near the Iraqi Karbala. In memory of those tragic events, faithful men perform self-flagellation during the lamentation procession. ${ }^{14}$

Under Ottoman rule, on the outskirts of the Botanical Garden, a mosque intended for the Sunni community was erected in 1723-1735. This, however, was destroyed in the midseventeenth century. ${ }^{15}$ Between 1846 and 1851, the architect Jovannie Scoudier undertook the task of restoring the building. However, this mosque was destroyed as well. The mosque which still exists and functions today in Tbilisi was built on the site of the previous one in 1895 .

The existing mosque was built of red brick, on a rectangular plan. In the longer walls of the main part of the building there are ten narrow, arched windows. The entire building is covered with a gabled tin roof. The outstanding minaret is of particular note, constructed on a square plan with cut angles, thereby forming an octagon. The main part of the minaret, like the walls of the mosque, was built of red brick. Tall sharp-arched windows were incorporated into the wider walls. The highest part of the minaret is topped with a gallery with a balustrade. In the past, it was from this place muezzin summoned the faithful to pray. The whole construction is

\footnotetext{
${ }^{11}$ LEVINE, Joshua. Future shock. In: Well, 11, 2014, p.131.

${ }^{12}$ GACHECHILADZE, Revaz. Social-geographical problems of a metropolitan region within a Soviet republic (a case study of Tbilisi metropolitan region, Georgia). In: Geoforum, 21, 1990, pp. 475-482.

${ }^{13}$ NACHKEBIA, Maia. Theme of the original sin in Georgian baroque literature. In: Pro Georgia 29, 2019 , p. 111.

${ }^{14}$ KIRSTE, Reinhard, SCHULTZE, Herbert. Święta wielkich religii. Kalendarz międsyreligijny [Holidays of great religions. Interreligious calendar]. Warszawa: Verbinum, 1998, pp.71-72.

${ }^{15}$ MATVEEVA, Anna. The South Caucasus: Nationalism, Conflict and Minorities. London: MRGInc., 2002, p. 7.
} 
crowned with a roof with an onion-shaped turret above it, topped with a crescent.

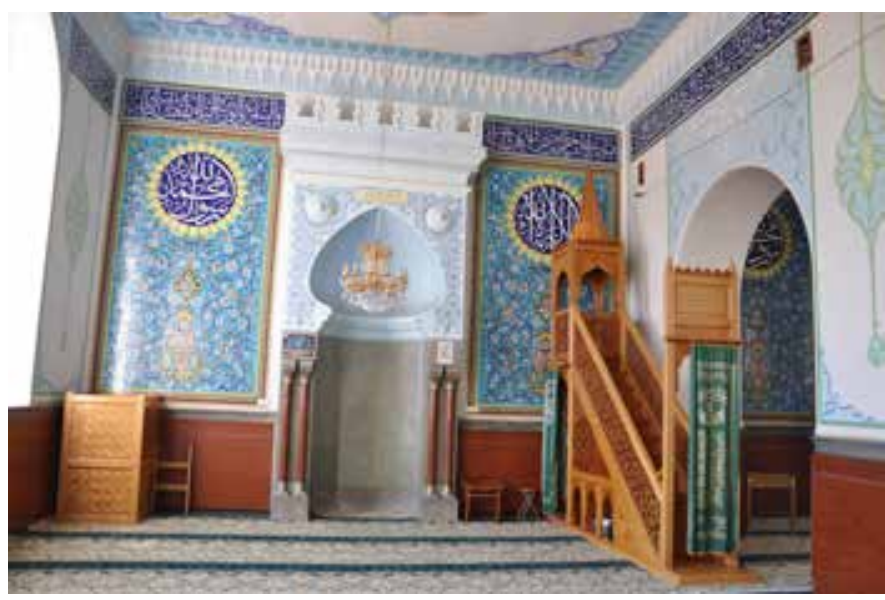

Fig. 3: Musalla, mihrab and mimbar in Jumah Mosque in Tbilisi

The entrance to the mosque is from Botanikuri Street. Large rectangular wooden doors with the name of the mosque placed above them in Georgian, Arabic, English and Russian, lead to a spacious corridor containing entrances to the mosque offices and the main prayer room, known as the musalla. A characteristic feature of Tbilisi musalla are two mihrabs and two minbars, separated by two arches supported on columns. A mihrab is a semicircular niche in the wall of a mosque, often richly ornamented, that indicates the qibla, that is, the direction of the Kaaba in Mecca. Muslims must face the holy city of Mecca when praying. A minbar is elevation in a mosque, a kind of pulpit from which the chairman of the prayer gives a sermon. ${ }^{16}$ At present, this musalla space is open, but in the past it was separated into Sunni and Shia prayer areas. ${ }^{17}$ The walls of the prayer room are richly decorated, in a manner typical of Muslim culture, filled with floral and calligraphic ornaments. The interior decorations are in white and shades of blue, with yellow accents that blend well with the wooden furniture of the mosque, namely, the minbar and shelves for Qur'ans and prayer books. Religious texts, placed in the upper part of the walls on ceramic tiles, refer to the Qur'an, reminding readers of the Muslim confession of faith, proclaiming that Allah is God, and Muhammad his prophet. ${ }^{18}$ Above the prayer room there is a balcony which serves as a gallery for women or youth (Fig. 3).

The last significant transformation of the mosque took place in its spiritual dimension. Due to the fact that the Shi'a community of Tbilisi and the surrounding area do not have their own mosque, they pray here alongside the Sunnis, without a trace of mutual animosity, which makes it one of the few mosques in the world where both communities pray side by side. Until 1996, the Sunni and Shia communities prayed in separate musalla, but this practice has since been abandoned.

In the vicinity of the city, there are other places of worship where followers of Islam gather. One is the new Ahli Bayt Shia Mosque, located in the village of Ponichala, in the suburbs of Tbilisi. Its construction began in 2008, and the opening took place on July 17, 2011. The venture was feasible thanks to the financial support of the Iraqi Ayatollah. ${ }^{19}$ The building was constructed on a square plan and occupies 1,000 square meters; it can accommodate 450 people. The whole construction is crowned with a dome. The two-story structure has

\footnotetext{
${ }^{16}$ CURATOLA, Giovanni. Islam. Visual Encyclopedia of Art. Florence: SCALA Group. 2009, pp. $312-313$.

${ }^{17}$ KILICASLAN, Hare. AKTUMSEK, Hulya. The creative drama method in cultural heritage education: Bursa Grand Mosque. In: Muzeológia a kultúrne dedičstvo, 8, 2020, pp. 5-7.

${ }^{18}$ SMIGEL, Michal, CHERKASOV, Aleksandr, KMET', Miroslav. Life and traditions..., pp. 38-42.

${ }^{19}$ LILES,Thomas, BALCI, Bayram. Georgia. In: SCHARBRODT, Oliver. AKGÖNÜL, Samim (ed.) Yearbook of Muslims in Europe. Leida: Brill, 2018, p. 271.
} 
numerous semicircular windows, reminiscent of traditional Muslim architecture. The décor of the interior of the prayer room is simple: white walls decorated with subtle calligraphies, and the floor adorned with green carpets. The mihrab is integrated into the wall. ${ }^{20}$

\section{Balconies}

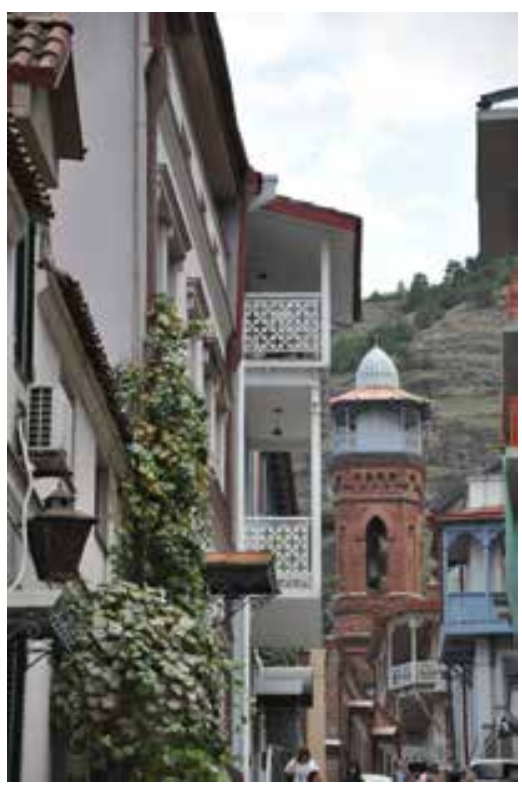

Fig. 4: Mosque and balconies in Tbilisi

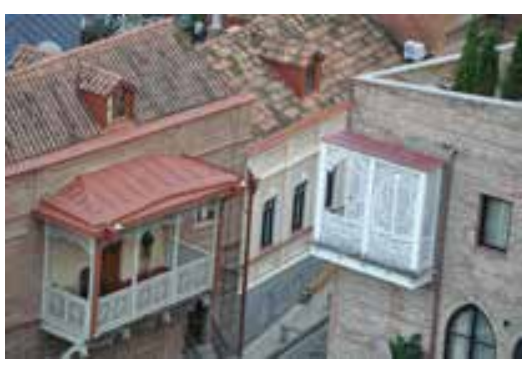

Fig. 5: Mashrabiyas on balconies

In Old Tbilisi many ancient elements of architecture have been preserved. Noteworthy are the renovated colourful tenement houses situated along the winding streets, characterized by asymmetrical roofs. However, what really deserves the attention are the balconies with wooden structures complemented with decorative bars by the Ottoman Turks (Fig. 4). In architecture, they refer to well-known balconies typical of Eastern Islam, known in Arabic as mashrabiyas. In Muslim construction, they were a kind of veil, comparable to the principles of hijab, that is, the manner of dressing of the faithful, with the house serving as a strengthened hijab, serving as a special protection for women. The Easterners' hospitality and their eagerness to welcome strangers made it necessary to designate private rooms in the home, called haram, to which visitors have no entry. Most often, these private rooms were placed on the first floor of the house, and it was in these rooms that mashrabiyas (Fig. 5) were built. A mashrabiya is a kind of decorative wooden blind surrounding the balcony or window. Such a construction ensured intimacy and protection from strangers, especially for women. ${ }^{21}$

\section{Bathhouses}

The primary remnant of Persian rule in sixth-century Tbilisi is the still functioning sulfur baths. The oldest and, in addition, architecturally most interesting baths are located in Abanotubani district, which, from the very beginning was inhabited by the Muslim community. Probably for this reason, the Georgian baths were modelled on Middle Eastern hammams. The Turkish hammam style of public bath has long been popular throughout the Muslim world, and it came to Europe with Islam. It is typically a spacious building with many rooms, each dedicated to a different ritual, starting from moistening the body, then massage with exotic oils, and finishing with an ordinary bath. The interiors of hammams are characterized by rich decorations. The colorful mosaics decorating the walls, almost identical to Turkish and Iranian ornamentation,

\footnotetext{
${ }^{20}$ CAGARA, Dominik. Neighbours Struggle to Deal with Religious Tension in Tbilisi's Muslim Settlement. http:// dfwatch.net/neighbours-struggle-to-deal-with-religious-tensionin-tbilisis-muslim-settlement-40344 (accessed 22 January 2021).

${ }^{21}$ SULIMA, Magdalena. Miejsca swoje i miejsca obce w przestrzeni domowej w wierzeniach religijnych [Familiar and unfamiliar places in the space of the home in religious beliefs]. In: Architecturae et Artibus, 1, 2009, p. 74.
} 
make the interior design of the Tbilisi's baths very oriental in style. ${ }^{22}$

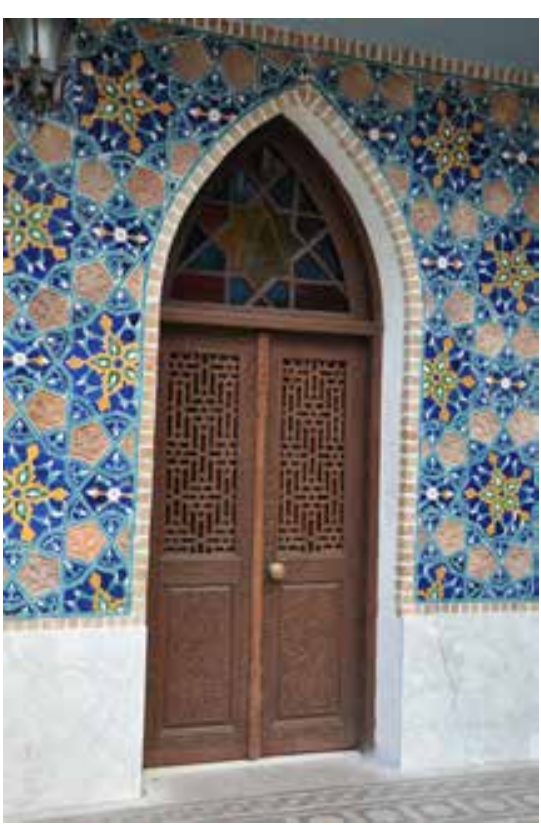

Fig. 6: The facade of the historical bathhouse with a glazed mosaic

Of particularly note is the eighteenth-century Orbeliani bathhouse (Fig. 1). It owes its name to the Orbeliani family, who owned the building as early as 1700 . This respected Georgian family, which gave the world many writers, politicians and military leaders, including generals, had a significant influence on Georgia and its development. Sulkhan-Saba Orbeliani was the author of the first Georgian dictionary. The building is characterized by an oriental facade, referring to the Iranian iwan - an element of Persian architecture, located in the front wall of the building, opening to the courtyard. Usually, it is the main entrance to a landmark building such as a palace, mosque or madrassa. It can also act as a gallery from which there are numerous doors to the interior of the building. The Orbeliani bathhouse is entered through three tall carved wooden doors. The second floor of the iwan is a balcony, secured by a simple balustrade, allowing visitors to admire the intricate mosaic of the front wall. The facade of the historical bathhouse in Tbilisi is lined with a glazed mosaic in shades of blue and yellow (Fig. 6). Also of note are the two bath towers, reminiscent of miniature minarets, characteristic of Persian architecture, located in the front wall. An oft-cited fact is that in 1829 Aleksander Pushkin stayed there, once sneaking into a bathhouse disguised as a woman. Later he said: "I have never experienced anything more luxurious than Tiflis baths." ${ }^{23}$ It was commemorated with an appropriate plaque placed in the bathhouse. Alex-

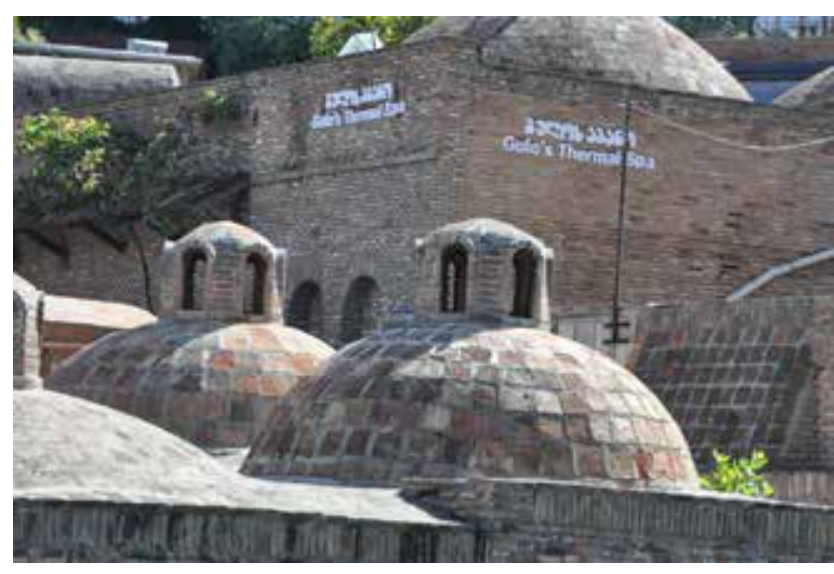

Fig. 7: Royal Baths andre Dumas philosophically asked: "Why doesn't Paris, the city of physical pleasures, have such baths?"24

Next to the spectacular Orbeliani bath are the extensive Royal Baths. They are located underground, and one of the characteristic features is the mult-domed vault, which extends above ground level. Light reaches the interior of the bathhouse through the openings in the domes (Fig. 7). Persian documents mention that in the thirteenth century Tbilisi there were nearly 70 bathhouses with water

\footnotetext{
${ }^{22}$ CICHOCKI, Nina. Continuity and change in Turkish bathing culture in Istanbul: The life story of the Çemberlitaş Hamam. In: Turkish Studies, 6, 2005, pp. 93-112.

${ }^{23}$ Lažnie siarkowe w Tbilisi [Tbilisi Sulfur Baths]. http://veturo.pl/article/3021/laznie-siarkowe-w-tibilisi-atrakcje-ciekawe-miejsca-gruzja/ (accessed 22 January 2021).

${ }^{24}$ Tbilisi Sulfur Baths. The best place for a soak in winter. https://www.bestgeorgian.com/tbilisi-sulfur-baths/ (accessed 22 January 2021).
} 
at temperatures of up to $27^{\circ} \mathrm{C}$. Currently, the water temperature in Tbilisi baths ranges between $32^{\circ} \mathrm{C}$ and $46^{\circ} \mathrm{C}$. The water has an intense sulfur smell, reminiscent of rotten eggs. The owners of the baths offer their clients numerous attractions, such as a peculiar massage involving fairly strong stokes with wet cloths, as well as local dishes and a wide selection of spirits.

\section{Caravanserai}

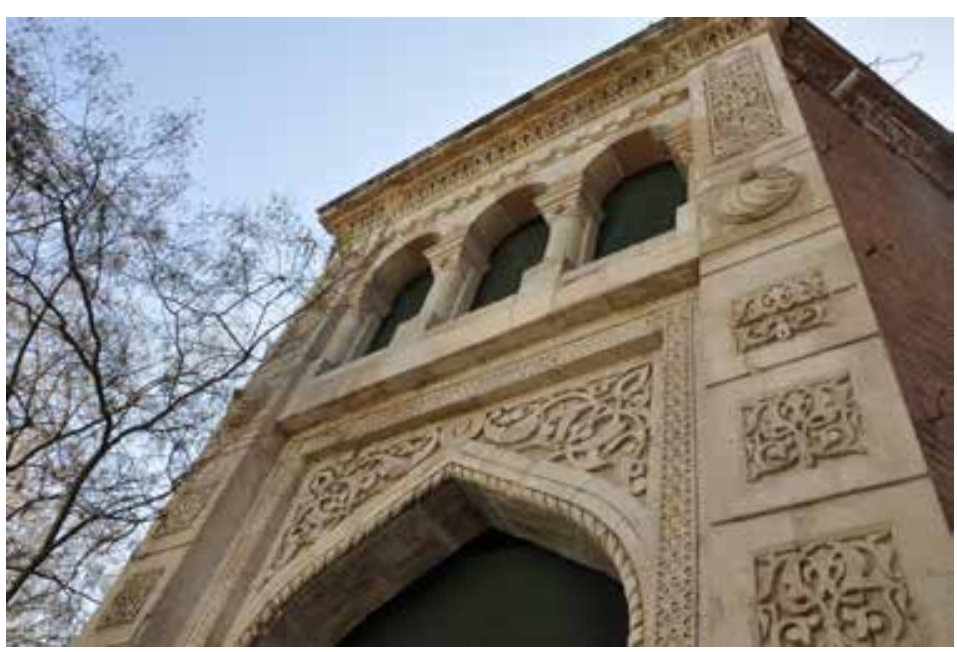

Located where Europe meets Asia, Tbilisi was an important city on the trade route between the two continents. Long caravans of camels, donkeys and horses carrying various exotic goods were constantly passing through the city. ${ }^{25}$ Caravanserai provided a resting point for caravan owners and wandering traders, offering large roofed halls which served as shelters for animals and warehouses for the Fig. 8: Caravanserai caravans and their contents, along with rooms for the fatigued travellers. In the second half of the nineteenth century, there were 17 caravanserai in the capital of Georgia. ${ }^{26}$ Today, the historic caravanserai erected in 1894-95, located at Kote Afkhazi, still deserves attention (Fig. 8). It has been partially restored, returning the main entrance to its former glamour. The floral ornamentation that decorates the façade was revitalized and the façade was tiled with sandstone. At that point, the restoration works stopped. Ultimately, the intention is that the building should house a shopping centre. ${ }^{27}$

One of the former Tbilisi caravanserais, located at 8/10 Erekle Str. was adapted as a residential building, with a ground-floor commercial space - currently a bar with the intriguing name KGB Still Watching You. In the inner courtyard of the caravanserai, despite much damage and the negligence of its tenants, one can still admire unique nineteenth-century decorative elements expressive of the artistry and the ancient beauty of the building.

The eighteenth-century caravanserai located at 8 Sioni Street was rebuilt to serve the needs of the Historical Museum of Tbilisi. There is a high probability that in the years 1911-12, the reconstruction of the façade of the building, renamed Artsrunis by the municipal museum, was managed by the Polish architect Aleksander Stanisław Rogojski, who was the city architect of

\footnotetext{
${ }^{25}$ SALUKVADZE, Joseph, GOLUBCHIKOV, Oleg. City as a geopolitics: Tbilisi, Georgia. A globalizing metropolis in a turbulent region. In: Cities, 52, 2016, p. 39-40.

${ }^{26}$ About History. Camels in 19th Century Tiflis. https://georgiaabout.com/2014/08/13/camels-in-19th-century-tiflis/ (accessed 22 January 2021).

${ }^{27}$ FREDERIKSEN, Martin. A gate, but leading where? In search of actually existing cosmopolitanism in post-Soviet Tbilisi. In: HUMPHREY, Caroline, SKVIRSKAJA, Vera (Eds.). Post-cosmopolitan cities: Explorations of urban coexistence. New York: Berghahn Books, 2012, pp. 120-140.
} 
Tblisi in the early twentieth century. He oversaw many architectural projects in the capital and other cities of Georgia. ${ }^{28}$

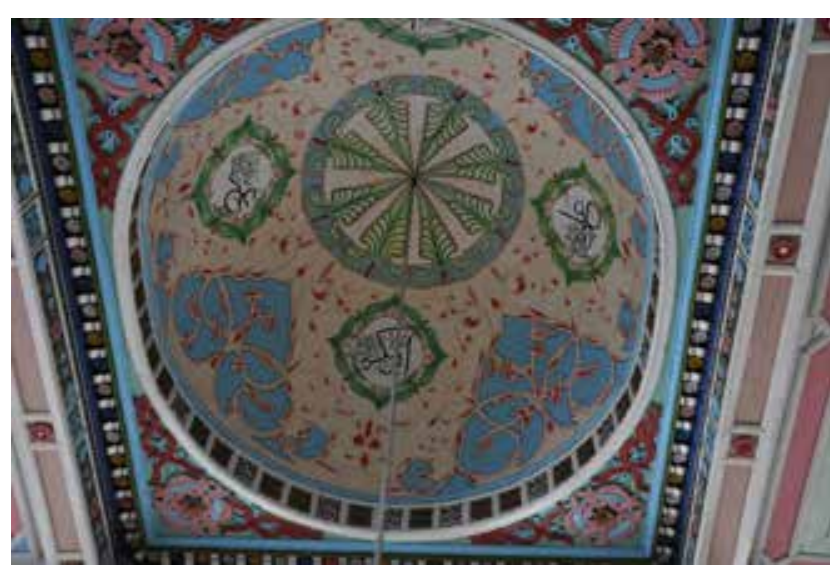

Fig. 9: Inside the dome mosque Batumi

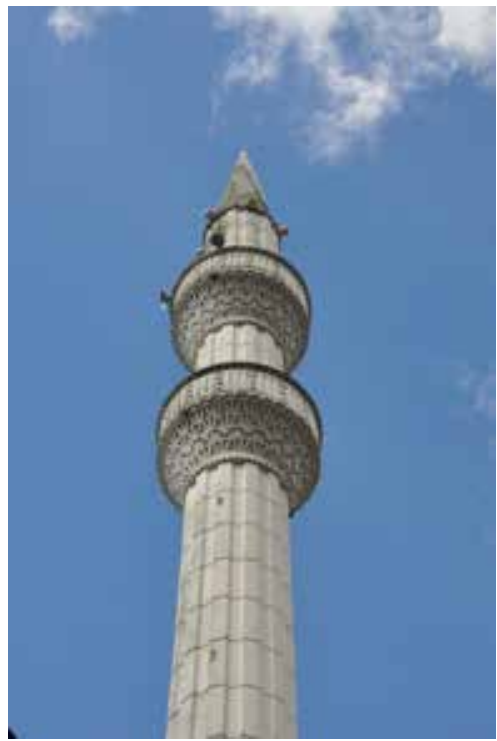

Fig. 10: Minaret of Orta Jame Mosque in Batumi Lenin Square.

\section{Batumi}

The seaside city of Batumi is the capital of the autonomous republic of Ajara in Georgia. The centuriesold presence of Islam in this area is no longer clearly visible. In the past, the city was home to three mosques, all built in the nineteenth century two brick and one wooden. The only one to survive to this day is Orta Jame (jame meaning mosque).

The Batumi Aziziye Mosque was founded in 1861 on the initiative of Perteva Walide Sultana, the wife of Sultan Mahmud II and mother of Sultan Abdul Aziziye, hence the name of the mosque. The building was built on a hexagon plan, with a slender minaret next to it. Despite being Batumi's oldest monument, and an extremely valuable one at that, it was dismantled in Soviet times to make way for

The small wooden Mufti Maglasin Jame was located on the coast. The causes and date of its destruction are unknown. ${ }^{29}$

Undoubtedly, the Orta Jame, located in Kutaisi Street, built in 1886, is well worth a visit. Founded by Aslan Beg Khimshiashvili, a Muslim and Georgian nobleman, it is one of the finest examples of Islamic art in Adjara. The construction was co-funded by the nobleman's mother. The interior of the mosque was decorated by artist brothers from Lazia (Fig. 9). The Laz are an indigenous ethnic group who mainly live along the Turkish and Georgian Black Sea coast. The building was constructed on a rectangular plan and appears similar to an ordinary residential building. However, its Muslim character arises from its tall white pencil-like minaret (Fig. 10) which towers over the city, as well as the dome over the main part of the building. The minaret was destroyed in Soviet times and was not rebuilt until 1992. In 2012, a gilded dome was built over the mosque. The mosque is popularly called the Jamia in the Middle because it was previously located between two other places of worship. Unfortunately, as a result of

\footnotetext{
${ }^{28}$ OPASKA, Janusz. Działalność polskich architektów w Tbilisi w XIX i początkach XX wieku [Activities by polish architects in Tbilisi in the nineteenth and early twentieth century]. In: Kwartalnik Architektury $i$ Urbanistyki, 57, 2012, p. 15.

29 Batumi Mosques. https://abeonatravel.ge/history-and-facts/autonomous-republic-of-adjara/religious-places-of-adjara/batumi-mosques/?lang=en (accessed 22 January 2021).
} 
historical turmoil, the other buildings were destroyed. ${ }^{30}$ From 1932 to 1946, the mosque was closed. Currently, the main prayer room of the Orta Jame can accommodate nearly 1,500 people. According to Mufti Avtandil Kamashidze, it is frequented daily by approximately 200 people who come for the daily prayer, with numbers reaching up to 400 on Fridays. Followers of Islam living in Batumi usually gather at the mosque on religious holidays. ${ }^{31}$

\section{Other selected mosques of Georgia}

Apart from the impressive mosque in Batumi, in the Adjara region there are many small, usually wooden mosques which provide places of prayer for local communities. They are usually modest and neglected. Founded mainly in the nineteenth century, the mosques and other spiritual institutions were closed during the difficult times of the Soviet regime of the 1930s and, consequently, suffered slow decay and destruction. Minarets were demolished and mosques were adapted to serve social and economic purposes. Religious changes in Georgia began only in 1980. Wooden mosques still exist in the villages of Kokotauri, Gulebi, Chinkadzeebi, Kolotauri, Makhuntesti and Gegelidzeebi. ${ }^{32}$ Architecturally interesting mosques can also be found in other regions of Georgia, such as in the Lower Kartli region in the south of Georgia, along the border with Armenia and Azerbaijan. In Algeti, there is a mosque with a tall cylindrical minaret; it provides a space for prayer and meetings for the Azeri community. There is a mosque with six domes in Imiri; the largest dome is above the prayer room, and there are four smaller domes in the corners of the building's roof. The tall cylindrical minaret is crowned with a small dome. ${ }^{33}$

Marneuli is a town in Lower Kartli inhabited mainly by Azeris, who constitute $83 \%$ of the 24,000 inhabitants. In 1793, the Imam Ali Mosque was built, but it was gradually destroyed in the Soviet era. It was only in 1998 that the local Muslim community, using its own financial resources, restored the building to its former glory. Services were resumed in 2000, and the mosque was managed by an independent shura, a type of Muslim council. The mosque was built from red brick on a square plan and covered with a dome. Daylight reaches the interior through tall arched windows. The mosque in Marneuli is one of the largest in Georgia. In 2014, a dispute arose between the local Azeri Muslim community and the Georgian Muslims Department about the Imam who was appointed as a supervisor by the state authority. The dispute centred around the authority of the State Agency for Religious Affairs, established in 2011 to manage the buildings of religious institutions in Georgia. Under the agency's auspices, the Imam Ali Mosque was entered into the register as a state property, which the local community disagreed with. At the same time, the Georgian administration leased the building to the Muslims community for 49 years. The Muslim representatives of the agency took the stance that the situation in Marneuli was not exceptional, as similar situations had arisen in other parts of the country. The matter has been exaggerated to provoke tensions in the Azeri Muslim communities. ${ }^{34}$

\footnotetext{
${ }^{30}$ LILES, Thomas. Islam and Religious Transformation in Adjara. Flensburg: ECFM, Working Paper, 2012, pp. 18-20. ${ }^{31}$ SANIKIDZE, George, WALKER, Edward. Islam and Islamic Practices in Georgia. Berkeley: UCBerkeley, 2004, p. 13. ${ }^{32}$ About Sights - 19th Century Mosques in Ajara. https://georgiaabout.com/2013/08/20/19th-century-mosques-in-ajara/comment-page-1/ (accessed 22 January 2021).

${ }^{33}$ ZELKINA, Anna. Islam and politics in the North Caucasus. In: Religion, State and Society, 21, 1993, pp. 115-124.

${ }^{34}$ The Marneuli Mosque Dispute. http://georgiatoday.ge/news/7937/The-Marneuli-Mosque-Dispute (accessed 22 January 2021).
} 
In May 2016, the new Mosque of Imam Hussain was opened in Marneuli, founded by the office of the Grand Ayatollah Sayyid Ali Sistan. The grand opening was attended by numerous Iranian, Azeri and Georgian politicians. The new mosque was inspired by the traditional architecture of Iran. The Persian style is expressed through specific spatial concepts and in the decorative multi-coloured ceramic cladding which features printed fragments of Arabic and quotations from the Qur'an. An interesting architectural element is the dome that tops the building. Its shape refers to the domes that crown the largest and most famous mosques of Iran, such as the Imam Mosque in Isfahan. Buildings in Iran and in Persian-influenced areas are characterized by a special type of arch and vault profile. This architectural element, known as the Persian arch, arose from the combination of various geometries, featuring both a semicircular arc and a sharp arch, with a profile consisting of two sections of a circle, morphing into curves which converge into a pointed peak. Although the construction of a dome based on such an arch presents numerous technical problems, and requires a special scaffolding to cover the dome, the aesthetic impact is great. The Persian arch, realised in three dimensions in pointed-arched barrel vaults or domes, creates light and elegant buildings. It is one of the most characteristic means of expressing the Persian style. ${ }^{35}$

The dome of Imam Hussain Mosque in Marneuli is covered in marine blue terracotta tiles. The elevation of the mosque also refers to the Persian style. It is decorated with glazed tiles decorated in shades of blue. The art of making this kind of wall covering dates back to ancient times, while the peak of production was in the times of the Safavidi dynasty, in the sixteenth to eighteenth centuries. ${ }^{36}$ The new mosque in Marneuli is 350 square meters and has three floors. The tall Persian arched windows, glazed with panes with carved overlays, give the building a light appearance. There are six windows in each of the longer walls and four in the façade. The main entrance to the building resembles an iwan, as the niche opens to three sides.

\section{Conclusions}

Muslims represent Georgia's second largest religious community. Islam has influenced the community not only in spiritual, but also in cultural terms, the most vivid example of which is the architecture that references the heritage of Islam. The many centuries throughout which Muslims have been present in Georgia mean that Islamic culture, art and architecture has been deeply engraved on the landscape. The difficult and often painful history of Georgia as a multicultural society is intertwined with the peaceful coexistence of representatives of various religions. An example of the peaceful life of communities with different beliefs is undoubtedly the mosque in Tbilisi, which is a common place of prayer for Sunni and Shi'a Muslims. Cultural diversity is also reflected in art. The presence of Arabs and Persians is expressed through beautiful buildings with architectural details brought over from the Middle East. However, attention should also be given to local peculiarities, buildings serving as mosques which refer in their own way to local construction practices. Such buildings can be seen as a symbol of the perseverance of the Georgian Muslim community in cultivating a local religious tradition. IIn many cases, people's homes served as mosques. This side of Georgia's Islamic heritage highlights two main problems that the country's Muslim communities had to face. The first was the lack of financial resources for the construction of grand mosques that would provide not

\footnotetext{
${ }^{35}$ STIERLIN, Henri. Oriental Treasures in the Mediterranean: From Damascus to Granada. New York: Rizzoli, 2005, pp. $44-45$.

${ }^{36}$ STIERLIN, Henri. Islam. Berlin: Taschen, 2002, pp.140-141.
} 
only places of prayer but centres of Muslim culture. The second was the struggle to preserve the religious tradition for subsequent generations.

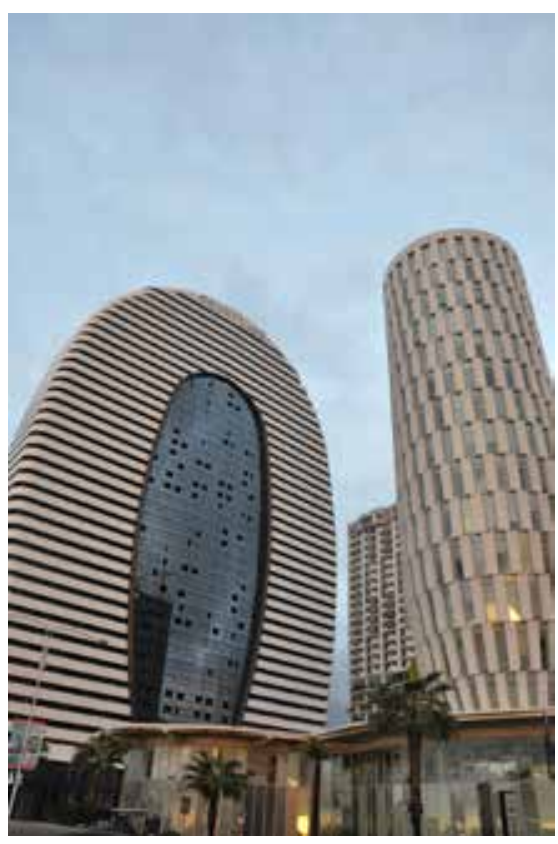

Fig. 11: Hotels in Batumi

In the past, Muslim architecture in the Christian land of Georgia was a symbol of the dominance of occupying forces and the suppression of local culture and religion. But today, a new trend can be seen in Georgian architecture, offering a symbol of modernity. This trend is especially visible in Batumi, where it consists of massive commercial buildings, dominated by hotels and apartment buildings with flats for rent, located along the seaside promenade. The offer is undoubtedly directed at tourists and those who profit from the tourism industry. However, attention should be paid to the investors who fund these architectural enterprises. Increasingly, these investments are made by Turkish businessmen who see opportunities in the Black Sea resort. In this way, modern architecture, financed by foreign capital, is introduced into the landscape of Georgia. There are hotels which host casinos, which are prohibited by Islam. At the same time, a significant group of tourists coming to Batumi are Turks and Iranians. Muslim tourists in the characteristic costumes of the Middle East region can be found throughout the city. An exclusive hotel (Fig. 11) financed by investors from Turkey was also built in Tbilisi. It seems, however, that in the Georgian capital, modern buildings do not collide with the historic district of the city, as it is clearly separated from the developing city. In any case, Old Tbilisi is protected by cultural heritage laws and no reconstruction is allowed in the district. ${ }^{37}$ Of course, modern utility architecture financed by Turkish investors does not make any reference to traditional Turkish styles from the Golden Age of Ottoman rule, epitomised by the rule of Suleiman II the Magnificent, who reigned from 1520 to 1566, ${ }^{38}$ or the court architect Sinan, who served four Turkish sultans. ${ }^{39}$ The buildings in question, such as the aforementioned exclusive hotels on the promenade in Batumi, follow modern global architectural trends. They are characterised by a taste for monumentalism, being 40 or even 50 storeys high. They often do not comply with conservation rules, damaging the historical and cultural identity of many areas. Georgian building law allows developers to purchase additions to the normal height restrictions specified in zoning regulations. ${ }^{40}$

Monumentalism was obviously an element in the history of Turkish architecture, indicating the power of the ruler. A ruler who could erect a powerful structure - such as the Sultan Ahmed

\footnotetext{
${ }^{37}$ VAN ASSCHE, Kristof, SALUKVADZE, Joseph. Tbilisi reinvented: Planning, development and the unfinished project of democracy in Georgia. In: Planning Perspectives, 27, 2011, pp. 1-24; GOLUBCHIKOV, Oleg. PHELPS, Nicholas. The political economy of place at the post-socialist urban periphery: governing growth on the edge of Moscow. In: Transactions of the Institute of British Geographers, 36, 2011, pp. 425-440.

${ }^{38}$ ATIL, Esin. The Age of Sultan Süleyman the Magnificent. New York: Harry N. Abrams Inc., 1987, p. 17-27.

${ }^{39}$ RABB, Peter. We are all servants here!" Mimar Sinan -architect of the Ottoman Empire. In: Periodica Polytechnica Architecture, 44, 2014, pp. 17-37.

${ }^{40}$ SALUKVADZE, Joseph, GOLUBCHIKOV, Oleg. City as a geopolitics..., p. 48.
} 
Mosque, ${ }^{41}$ also known as Blue Mosque in Istanbul - would be perceived as a powerful military force, no doubt in command of a strong and numerous army. And although this principle may have been appropriate in the Renaissance era, it raises questions of particular importance to researchers of cultural heritage, museologists and art historians today. How much can the cultural heritage of the local community be allowed to intervene in the name of political and economic gains? Does an overly liberal construction policy marginalize architectural cultural heritage? Is the price for intensive urban development too high?

The 2015 Doing Business survey ranked Georgia third in the world for ease of obtaining a building permit and the first for property registration. ${ }^{42}$ Such liberalism poses a threat to the protection of cultural heritage. It is easier to demolish an old building than to revitalize it and build a modern building in its place. Many examples can be found in the streets of Tbilisi: Barnovi, Paliashvili, Piqris Gora and Sairmis Gora to name but a few. Is consent to the growing interference of overseas capital in the Georgian state an appropriate political strategy? Development is a natural stage of humanity, but it seems that each step into the future should be marked with special care for the past.

\section{References}

About History. Camels in 19th Century Tiflis. https://georgiaabout.com/2014/08/13/camelsin-19th-century-tiflis/ (accessed 22 January 2021).

About Sights - 19th Century Mosques in Ajara. https://georgiaabout.com/2013/08/20/19thcentury-mosques-in-ajara/comment-page-1/ (accessed 22 January 2021).

ANANIEV, Vitaly. (2018). Fyodor Shmit's "Social Museum": On the Theorization of the Form and Purposes of Museums in Early Soviet Russia. In: Muzeológia a kultúrne dedičstvo, vol. 6, no. 1, pp. 33-41. ISSN 2453-9759.

ASATRIAN, Garnik, MARGARIAN, Hayrapet. (2004). The Muslim community of Tiflis (8th19th Centuries). In: Iran and the Caucasus, vol. 8, no. 1, pp. 29-52. ISSN 1609-8498.

ATIL, Esin. (1987). The Age of Sultan Süleyman the Magnificent. New York: Harry N. Abrams Inc. ISBN 0894680986.

BARANOWSKI, Bogdan, BARANOWSKI, Krzysztof. (1987). Historia Gruzji [History of Georgia], Warszawa: Ossolineum. ISBN 9788304023451

Batumi Mosques. https://abeonatravel.ge/history-and-facts/autonomous-republic-of-adjara/ religious-places-of-adjara/batumi-mosques/?lang=en (accessed 22 January 2021).

CAGARA, Dominik. Neighbours Struggle to Deal with Religious Tension in Tbilisi's Muslim Settlement. http://dfwatch.net/neighbours-struggle-to-deal-with-religious-tensionintbilisis-muslim-settlement-40344 (accessed 22 January 2021).

CHERKASOV, Aleksandr, KOROLEVA, Larisa, BRATANOVSKII, Sergei. SMIGEL, Michal. (2018). Sacred pagan temples in the Caucasus region: characteristic features. In: Muzeológia a kulturne dedičstvo, vol. 6, no. 2, pp. 59-69. ISSN 2453-9759.

\footnotetext{
${ }^{41}$ GOODWIN, Godfrey. A History of Ottoman Architecture. New York: Thames \& Hudson, 1987, pp. 215-245.

${ }^{42}$ THE WORLD BANK, Doing Business 2015: Going beyond efficiency (12th ed.). Washington: The World Bank, 2014, p. 187.
} 
CICHOCKI, Nina. (2005). Continuity and change in Turkish bathing culture in Istanbul: The life story of the Çemberlitaş Hamam. In: Turkish Studies, vol. 6, no. 1, pp. 93-112. ISSN 1468-3849.

CORSO, Molly Georgia: What's the Definition of Tolerance? https://eurasianet.org/s/ georgia-whats-the-definition-of-tolerance (accessed 22 January 2021).

COUNTRY WATCH. (2018). Georgia. 2018 Country Review. Houston: CWInc. ISBN:1605236799.

CURATOLA, Giovanni. (2009). Islam. Visual Encyclopedia of Art. Florence: SCALA Group. pp. 312-313. ISBN 978-88-8117-808-7.

FREDERIKSEN, Martin. (2012). A gate, but leading where? In search of actually existing cosmopolitanism in post-Soviet Tbilisi. In: HUMPHREY, Caroline. SKVIRSKAJA, Vera (eds.). Post-cosmopolitan cities: Explorations of urban coexistence. New York: Berghahn Books, pp. 120-140. ISBN 978-0857455109.

GACHECHILADZE, Revaz. (1990). Social-geographical problems of a metropolitan region within a Soviet republic (a case study of Tbilisi metropolitan region, Georgia). In: Geoforum, vol. 21, no. 4, pp. 475-482. ISSN 0016-7185.

GOLUBCHIKOV, Oleg, PHELPS, Nicholas. (2011). The political economy of place at the post-socialist urban periphery: governing growth on the edge of Moscow. In: Transactions of the Institute of British Geographers, vol. 36, no. 3, pp. 425-440. ISSN 0020-2754.

GOODWIN, Godfrey. (1987). A History of Ottoman Architecture. New York: Thames \& Hudson. ISBN 9780500274293.

KILICASLAN, Hare, AKTUMSEK, Hulya. (2020). The creative drama method in cultural heritage education: Bursa Grand Mosque. In: Mureológia a kulturrne dedičstvo, vol. 8, no. 1, pp. 5-17. ISSN 2453-9759.

KIRSTE, Reinhard, SCHULTZE, Herbert. (1998). Święta wielkich religii. Kalendarz międzyreligijny [Holidays of great religions. Interreligious calendar]. Warszawa: Verbinum. ISBN 8371920431.

LEVINE, Joshua. (2014). Future shock. In: Well, vol. 11, no. 2, p. 131-135.

LILES, Thomas. (2012). Islam and Religious Transformation in Adjara. Flensburg: ECFM, Working Paper.

LILES, Thomas, BALCI, Bayram. (2018). Georgia. In: SCHARBRODT, Oliver. AKGÖNÜL, Samim (eds.) Yearbook of Muslims in Europe. Leida: Brill, p. 271-299. ISBN 9789004386907.

Łaźnie siarkowe w Tbilisi [Tbilisi Sulfur Baths]. http://veturo.pl/article/3021/laznie-siarkowew-tibilisi-atrakcje-ciekawe-miejsca-gruzja/ (accessed 22 January 2021).

MATERSKI, Wojciech. (2000). Gruzja [Georgia]. Warszawa: Trio. ISBN 8385660909.

MATVEEVA, Anna. (2002). The South Caucasus: Nationalism, Conflict and Minorities. London: MRGInc. ISBN 1-85383-952-3.

NACHKEBIA, Maia. (2019). Theme of the original sin in Georgian baroque literature. In: Pro Georgia, vol. 29, no. 1, p. 109-118. ISSN 1230-1604.

OPASKA, Janusz. (2012). Działalność polskich architektów w Tbilisi w XIX i początkach XX wieku [Activities by polish architects in Tbilisi in the nineteenth and early twentieth century]. In: Kwartalnik Architektury i Urbanistyki, vol. 57, no. 1, p. 3-18. ISSN 0023-5865.

PRASAD, Connor. (2012). Georgia's Muslim Community: A Self-Fulfilling Prophecy? Flensburg: European Centre for Minority Issues.

RABB, Peter. (2014). We are all servants here!" Mimar Sinan - architect of the Ottoman Empire. In: Periodica Polytechnica Architecture, vol. 44, no. 1, pp. 17-37. ISSN 0324-590X. 
SALUKVADZE, Joseph, GOLUBCHIKOV, Oleg. (2016). City as a geopolitics: Tbilisi, Georgia. A globalizing metropolis in a turbulent region. In: Cities, vol. 52, no. 3, p. 39-54. ISSN 0264-2751.

SMIGEL, Michal, CHERKASOV, Aleksandr, KMET', Miroslav. (2017). Life and traditions of Caucasian Circassians: historical-comparative probe of travelogues of European travellers from the beginning of the 16th century to the half of the 19th century. In: Muzeologia a kulturne dedičstvo, vol. 5, no. 2, pp. 29-50. ISSN 2453-9759.

SULIMA, Magdalena. (2009). Miejsca swoje i miejsca obce w przestrzeni domowej w wierzeniach religijnych [Familiar and unfamiliar places in the space of the home in religious beliefs]. In: Architecturae et Artibus, vol. 1, no. 1, p. 67-76. ISSN 2080-9638.

SUNY, Ronald. (2009). The mother of cities: Tbilisi/Tiflis in the twilight of empire. In: VAN ASSCHE, Kristof, SALUKVADZE, Joseph (eds.). Urban culture and urban planning in Tbilisi: Where west and east meet. Lewiston: Mellen Press, pp. 17-58. ISBN 9780773448285.

SANIKIDZE, George, WALKER, Edward. (2004). Islam and Islamic Practices in Georgia. Berkeley: UCBerkeley.

STIERLIN, Henri. (2002). Islam. Berlin: Taschen. ISBN 9783822817865.

STIERLIN, Henri. (2005). Oriental Treasures in the Mediterranean: From Damascus to Granada. New York: Rizzoli. ISBN 978-8854400870.

Tbilisi Sulfur Baths. The best place for a soak in winter. https://www.bestgeorgian.com/tbilisisulfur-baths/ (accessed 22 January 2021).

The Marneuli Mosque Dispute. http://georgiatoday.ge/news/7937/The-Marneuli-MosqueDispute (accessed 22 January 2021).

THE WORLD BANK. (2014). Doing business 2015: Going beyond efficiency (12th ed.). Washington: The World Bank. ISBN 9781464803512.

VAN ASSCHE, Kristof, SALUKVADZE, Joseph. (2011). Tbilisi reinvented: Planning, development and the unfinished project of democracy in Georgia. In: Planning Perspectives, vol. 27, no. 1, pp. 1-24. ISSN 0266-5433.

ZELKINA, Anna. (1993). Islam and politics in the North Caucasus. In: Religion, State and Society, vol. 21, no. 1, pp. 115-124. ISSN 0963-7494. 